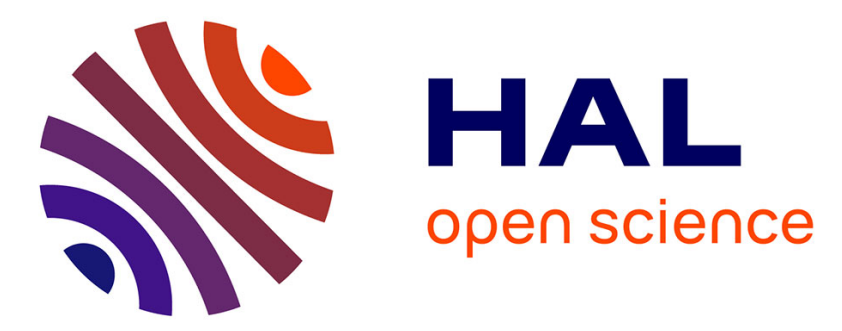

\title{
Improved management to limit milk production losses resulting from the transition to once-a-day milking in dairy sheep
}

\author{
Amandine Lurette, Catherine de Boissieu, Emmanuel Morin, Philippe \\ Hassoun, Charles-Henri Moulin
}

\section{To cite this version:}

Amandine Lurette, Catherine de Boissieu, Emmanuel Morin, Philippe Hassoun, Charles-Henri Moulin. Improved management to limit milk production losses resulting from the transition to once-a-day milking in dairy sheep. Small Ruminant Research, 2018, 165, pp.8-16. 10.1016/j.smallrumres.2018.06.007 . hal-02627098

\section{HAL Id: hal-02627098 \\ https://hal.inrae.fr/hal-02627098}

Submitted on 26 May 2020

HAL is a multi-disciplinary open access archive for the deposit and dissemination of scientific research documents, whether they are published or not. The documents may come from teaching and research institutions in France or abroad, or from public or private research centers.
L'archive ouverte pluridisciplinaire HAL, est destinée au dépôt et à la diffusion de documents scientifiques de niveau recherche, publiés ou non, émanant des établissements d'enseignement et de recherche français ou étrangers, des laboratoires publics ou privés. 


\section{Accepted Manuscript}

Title: Improved management to limit milk production losses resulting from the transition to once-a-day milking in dairy sheep

Authors: Amandine Lurette, Catherine De Boissieu, Emmanuel Morin, Philippe Hassoun, Charles-Henri Moulin

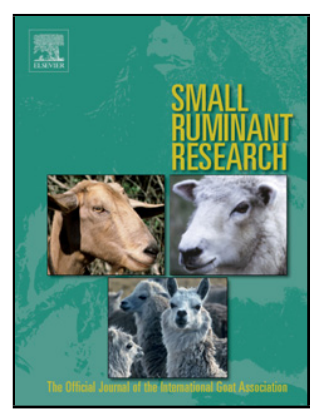

PII:

DOI:

Reference:

S0921-4488(18)30510-8

To appear in: $\quad$ Small Ruminant Research

Received date: $\quad$ 4-7-2017

Revised date: $\quad$ 7-6-2018

Accepted date: $\quad$ 13-6-2018

Please cite this article as: Lurette A, De Boissieu C, Morin E, Hassoun P, Moulin C-Henri, Improved management to limit milk production losses resulting from the transition to once-a-day milking in dairy sheep, Small Ruminant Research (2018), https://doi.org/10.1016/j.smallrumres.2018.06.007

This is a PDF file of an unedited manuscript that has been accepted for publication. As a service to our customers we are providing this early version of the manuscript. The manuscript will undergo copyediting, typesetting, and review of the resulting proof before it is published in its final form. Please note that during the production process errors may be discovered which could affect the content, and all legal disclaimers that apply to the journal pertain. 


\title{
Improved management to limit milk production losses resulting from the transition to once-a-day milking in dairy sheep
}

LURETTE Amandine ${ }^{*, a}$, DE BOISSIEU Catherine ${ }^{b}$, MORIN Emmanuel ${ }^{b}$, HASSOUN Philippe

a, MOULIN Charles-Henri ${ }^{3}$

a SELMET, INRA, CIRAD, Montpellier SupAgro, Univ Montpellier, Montpellier, France

${ }^{\mathrm{b}}$ Idele, antenne Toulouse

c SELMET, INRA, CIRAD, Montpellier SupAgro, Univ Montpellier, Montpellier, France

* corresponding author: amandine.lurette@inra.fr

\section{Highlights:}

- A model explores how once-a-day milking could affect milk yield of dairy ewes

- Once-a-day milking results in various response for farms presenting different leeway

- Management adaptations can limit losses due to once-a-day milking transition

\begin{abstract}
There has been increasing interest in once-a-day milking (ODM) in recent years. Despite the loss in milk production due to the reduction in milking frequency, ODM has several advantages for farm management, particularly labour savings. It has already been demonstrated that adapting management can compensate for the reduction in milk production, especially on dairy cow farms based on extensive grazing systems. The objective of this study was therefore to investigate the impact of management adaptations associated with a switch to ODM in a diverse range of dairy ewe farms in the 'Rayon de Roquefort', France, at the farm level. For that purpose, a model was developed to evaluate the ability of three flock management adaptations to compensate for losses due to the transition to ODM: (i) increasing the flock size, (ii) increasing the milking period and (iii) increasing grazing in the ewes' diet. The model results
\end{abstract}


show that depending on the farm, a transition to ODM on the first day of milking reduces the milk yield of the whole flock by $18-19 \%$ and causes an $8-16 \%$ decrease in household income. When the transition occurs around the turnout date, the impact on the performance of the flock is reduced, but so is the time spent on routine work. In the short term, it is possible to make adaptions to limit losses both in milk production and in household income by lengthening the milking period and/or by making better use of pasture. Conversely, increasing the number of milked ewes does not compensate for the loss of income. For each farm, a scenario was designed to provide a satisfactory trade-off between household income, milk delivery and routine workload. However, although the management adaptations are the same, their modalities of implementation depend on the farm concerned, which have different amounts of leeway. For the diverse range of farms tested, ODM represents a good compromise between flexible workload management and the performance of dairy sheep farms. ODM, during the whole or part of the milking period, is a useful farm management tool to manage both labour and grazing during strategic periods.

\section{Key words}

Livestock farming system; simulation; participatory research; farm level

\section{Introduction}

Compared with intensive dairy systems around the world, in which cows are milked twice a day or even more, reducing the milking frequency is still rare (Stelwagen et al., 2013). However, this practice is appropriate for more extensive dairy production systems, particularly those based on grazing (Clark et al., 2006). In systems in which less emphasis is placed on milk yield per cow, once-a-day milking (ODM) is a viable and practical alternative management system (Remond and Pomies, 2005; Clark et al., 2006). As labour costs constitute an important component of farm operating expenses (Stockdale, 2006), the savings associated with ODM are high. Similar to farms in other countries around the world, on most French farms, sheep 
are kept in small flocks and are looked after by the owner and his/her family, and ewes are generally milked twice a day (once in the morning and once in the evening), with a time interval as close as possible to 12 hours. ODM is thus one way to reduce the workload of dairy farmers (Seegers et al., 2003).

Several studies have focused on the quantitative and qualitative effects of a reduction in milking frequencies in dairy sheep systems and the advantages and disadvantages of this reduction at the dairy farm level to optimize milking routines and consequently to improve the quality of farmers' lives (Castillo et al., 209; O’Driscoll et al., 2010; Koutsouli et al., 2017). The results of these studies vary with the breeds tested and are in some cases contradictory, but all the studies reported that the most important consequence of once-a-day milking is a significant decrease in milk yield. This decrease ranges from 15\% (Negrao et al., 2001) to 48\% (Knight et al., 1993) and varies with the period when milking starts and with the length of the period (Negrao et al., 2001; Nudda et al., 2002). In addition to reducing the milk yield, the reduction in milking frequency can also affect the main constituents of the ewes' milk. For example, milk produced by ODM ewes has higher protein and lower lactose contents (Nudda et al., 2002; Prieto et al., 2013). Compared with other sheep breeds, the Lacaune ewe appears to be well adapted to once-a-day milking (Hassoun et al., 2016), as this high-yielding breed is able to store more cisternal milk than the medium-yielding Manchega ewes, suggesting a better adaptation of the "large-cisterned" Lacaune ewes to less frequent emptying (Castillo et al., 2009). These results differ from those obtained in dairy goats (Mocquot, 1978; Komara et al., 2010; Torres et al., 2013), for which higher losses, ranging from 26 to $36 \%$, have been reported. These results suggest that high-yielding goats and certain breeds of sheep cannot adapt to ODM.

Several management adaptations have been proposed to compensate for milk production losses due to the reduction in milking frequency. For example, the use of land that is not traditionally suitable for dairy systems due to hilly terrain or long walking distances can help farmers to maintain or increase the size of their herds without capital expenditure when the farm infrastructure (i.e., the number or size of milking parlours and breeds with a higher 
capacity of walking) may not support this increase (Bewsell et al., 2008). Likewise, for systems that are not limited by feed, it is possible to increase the stocking rate to compensate for the reduction in the yield of individual ewes associated with ODM (Amstrong and Ho, 2009).

Ranked in decreasing order, Italy, Greece, Romania, Spain and France are the five main ewe milk-producing countries in Europe. In the Mediterranean dairy area, the production of sheep and goat milk is continually increasing (Anonyme, 2016). Similar to other products with protected designation of origin, ewe milk cheese must be traditionally and entirely manufactured (prepared, processed and produced) within the specified region, thereby acquiring unique properties. The number of protected designation of origin cheeses made from ewe milk or from mixed ewe and goat milk is 17 in Spain (including Manchego), 4 in Italy (including Pecorino), 3 in France (including Roquefort) and 3 in Greece (including Feta). With the exception of Roquefort, the label specifications do not include the obligation to milk twice a day. If ODM turns out to be advantageous for breeders, the practice should spread. However, in the Roquefort area, the specifications of the cheese's protected designation of origin will also have to be changed, which is a long process whose outcome is uncertain and which would affect other components of the specifications. An ex ante evaluation of the potential advantages of introducing ODM on dairy ewe farms is needed before beginning the process. As mentioned above, there seems to be a consensus among dairy producers that a reduction in milking frequency has a positive impact on the farm workload and consequently on farmers' quality of life, but the decrease in milk production may affect both the farmers' income and the dynamics of the dairy companies that collect and process the milk. However, no data are available to evaluate these impacts at farm level. Modelling combined with scenario analysis (Bood and Postma, 1997) is one way to conduct an ex ante assessment of an innovative production system by simulating the different paths by which a farm may evolve. The aim of the present study was to assess the impact of ODM on annual milk delivery, household income and routine workload in a diverse range of French dairy ewe farms involved in Roquefort cheese value chains. The ability of three flock management adaptations to compensate for the loss caused by the transition to ODM was evaluated. The adaptations were (i) increasing the 
flock size, (ii) increasing the milking period and (iii) increasing grazing in the ewes' diet. Finally, the impact of the introduction of such flock management adaptations in dairy systems on milk collection and the consequences for protected designation of origin specifications are discussed.

\section{Materials and methods}

The approach used in this study combined building a model and scenarios to test the impact of the ODM associated with flock management on three levels of performance in a diverse range of dairy sheep farms (Figure 1).

First, scenarios corresponding to the implementation of the once-daily milking on dairy sheep farms were built. The scenarios represent (1) the modalities of ODM implementation (for a defined period or for the entire milking period) and (2) one or several flock management adaptations aimed at compensating for the loss in milk yield. A modelling tool called BOUSSOLE (Scilab - ESI group, Sophia Antipolis, France) was used to simulate scenarios for seven typical farms located in the Rayon de Roquefort.

The BOUSSOLE model was developed to simulate the functioning of a dairy sheep farm. It is a deterministic model that was coupled with a population dynamics model, a static model of the forage system and an Excel calculator for economic results.

\subsection{Diversity of dairy farms}

The Rayon de Roquefort, located in southern France, accounted for $67 \%$ of total ewe milk production in 2012-2013. In 2016, 1,716 farms were raising a total of 800,000 dairy ewes and supplying seven dairy companies that process Roquefort cheese and other dairy specialties. The Rayon has a range of different soil types and climate conditions. Situated between 400 and 1,000 metres in altitude, the Rayon de Roquefort is at the interface of Mediterranean and temperate climates. Roquefort dairies are traditionally open from December to August, resulting in a homogeneous model of livestock management, with a short mating period and a milking period for the whole flock that begins between November and February on $95 \%$ of the 
farms. During the early stage of lactation in winter, the ewes are housed and fed with stored forage. Aside from this specific homogeneity, the farms in the area use diverse flock management systems to produce milk out of season or diverse forage systems that vary depending on the pedoclimatic conditions and in their use of pasture.

Based on pluriannual monitoring of real farms, the Inosys Network (Jousseins et al., 2015) has built a database to depict the diversity of farming systems (Idele, 2012; Idele, 2014). The systems in the database account for the functioning of the most-representative farms in the area. In the present study, the diversity of the farms is illustrated by two local areas: the Ségala, where forage intensification on grasslands is possible with smaller flocks and a high milk yield per ewe, and the Causses, with poorer soil conditions, extensive rangeland, medium milk yield per ewe, and larger flocks. In each area, one farming system represents the main system encountered: in Ségala, on the farm termed INTENS (for intensive conditions), the milking period starts in late November, and in the Causses, on the farm termed EXTENS (for extensive conditions), milking starts in late February. The two other farming systems are more recent, with a shift in the milking period, which starts earlier in Ségala on the farm termed ODM_EARLY and later in the Causses on the farm termed ODM_LATE. On these farms, offseason milk (i.e., milk produced outside the period between December and August) is better valued.

The four farming systems are described in Table 1.

\subsection{The BOUSSOLE modelling tool}

The modelling tool was developed to evaluate the impact of the ODM at farm level. This tool enabled us to integrate both expert knowledge from stakeholders and data from experimental results and from Roquefort farm databases.

BOUSSOLE has three interactive modules representing (1) the flock and its diet, (2) the forage system, and (3) the farm's economy. The dynamic flock module was implemented with scilab (http://www.scilab.org/fr), which is a discrete model with a daily time step. The forage system 
and the farm economy modules are in a spreadsheet file. A general description of the model is provided in Appendix A.

\section{A sub-model of the dairy ewe flock system: the flock and its diet (Figure 2)}

A flock is characterized by demographic parameters (e.g., the culling rate and number of ewes at lambing), reproductive performance parameters (e.g., the mating date and artificial insemination rate in the flock), milking parameters (e.g., the milking period and level of milk production) and diet parameters (e.g., the type of diet, periods, and batching). The flock is represented by changes in the batches of animals. Over the course of a year, the flock passes through several successive physiological stages. The transition to another stage can occur at a fixed date (pre-recorded in the model or modified by the user; for example, the artificial insemination of ewes) or due to a previous event (for example, lambs are weaned 28 days after lambing). Within a batch of ewes, the fertilized mates and the lambings are lognormally distributed. The milk yield of the whole flock is simulated using predictive individual lactation curves (Lagriffoul et al., 2003) expressed as $M P_{t}=M P_{t 1} \times e^{-\left(a+b \times \ln \left(M P_{t 1}\right) \times\left(t-t_{1}\right)\right)}$, where $M P_{t 1}$ is the level of milk production on the first day of milking and $a$ and $b$ are coefficients. Different parameter values are used for ewes and ewe lambs. Feed requirements are calculated from the distribution of several diets depending on the period of the year.

The outputs of the flock module are used as inputs for the forage system module (by calculating the quantity of forage needed to feed the flock) and for the farm economy module (e.g., variables such as the number of lambs sold or the quantity of milk produced). Equations and parameters comprising the flock module are described in the supplementary materials (see Appendix A).

\section{A sub-model of the forage system (Figure 3)}

The forage system is based on the forage produced by the farm to meet the needs of the flock. This module represents the cropping pattern of the farm, rotations, operational sequences, and crop yields. The yields of forage for cutting or grazing are estimated (i) for grasslands using 
the HerbSim model (Duru et al., 2010) and (ii) for rangelands from the Pastoral Paddock Benchmark (Idele, 1999).

\section{A sub-model of the farm economy}

The farm economy module is fed with the outputs of the two previous modules. The module is also in a spreadsheet file and includes the balance sheet, the income statement, and the management accounts.

All the parameters are calibrated based on the original situation in which the ewes were milked twice a day. Thus, four versions of the model are available for the four farms modelled here. The economic conjuncture and the rules for milk payments are those from 2010. From the original twice-a-day milking scenario, the parameters values used to model the impact of the transition to ODM are based on the experimental results reported in Hassoun et al. (2016).

\subsection{Scenarios of the implementation of the transition to ODM at the farm level}

\subsubsection{Hypotheses used to build the scenarios}

The experimental results obtained with Lacaune breeds (Hassoun et al. 2016) were used to represent the milk yield losses for individual ewes. The immediate individual milk yield losses reached $22 \%$, resulting in a total loss of $14 \%$ for the whole milking period. Given these experimental results, one would expect that the implementation of the ODM cannot be represented by only a decrease in the yield of ewes' milk. Actually, the whole farm would be impacted by this key technical change. Beyond the direct impact on milk production, many hypotheses regarding the impact of management adaptations on other farm components related to the implementation of the ODM were defined.

\subsubsection{Two modalities of ODM implementation}

The conditions of the implementation of ODM on farms and the adaptations related to this transition were discussed in two technical committees meetings with stakeholders (farmers' associations, dairy companies, the Roquefort inter-professional organization, and extension 
and service organizations) and two meetings with a total of 12 dairy breeders. Given the huge immediate decrease in individual milk yield, two dates were tested for the transition to ODM: a transition at the beginning of the milking period and a transition around the turnout date.

A twice-a-day milking scenario served as a reference when the impacts of ODM were compared. The first ODM scenario (ODM1), in which the transition occurred on the first day of the milking period, resulted in an immediate $22 \%$ decrease in milk yield compared with the original twice-a-day milking system. The influence of the level of milk production on the first day of milking on the persistence of production is included in the model (represented by the lactation curve).

A second scenario (ODM2), in which the transition to ODM was delayed by 8 and 10 weeks into the milking period, resulted in an immediate $20 \%$ decrease in milk yield. This scenario could be used by breeders who aim to reduce their routine workload in spring while simultaneously limiting the reduction in milk production. The second scenario was run in two ways, once for early farms and once for late ones. In the early farms (termed ODMearly), the transition to ODM occurs one month before the turnout date, and in the late farms (ODMlate), the transition occurs one month after the turnout date.

As the level of milk production is affected by the transition to ODM, which was confirmed by experiments (Hassoun et al., 2016), the feeding system has to be adjusted to the scenario being tested. Based on discussions with technical experts and on the results of the experiments, several adaptations of the diet that depend on the feeding period concerned are modified as follows:

- No change from the baseline scenario either during preparation for the lambing period or during the lambing period itself.

- At the beginning of the milking period: the intake of forage remains the same, but the decrease in feed concentrate is proportional to the difference in milk production compared with the production under the baseline scenario of twice-a-day milking. 


\subsubsection{Adaptations of flock management to compensate for the loss in milk yield due to ODM}

Discussions concerning possible management adaptations to compensate for the loss caused by ODM focus on two types of options: (1) to increase milk production and (2) to reduce farm costs. It is generally acknowledged that increasing the flock size (termed FSI) or lengthening the milking period (termed MLI) can have a positive impact on milk production. Moreover, the possibility of reducing costs by increasing the feed intake on pasture (termed PFI) due to the longer grazing time allowed by the ODM work organization has been highlighted.

The three adaptations in flock management that can accompany the transition to ODM involve modalities of implementation that vary with the farm, as the seven farms do not have the same leeway and would respond differently to technical changes. For example, for the ODMearly farm, with 273 milking days, it would be difficult to lengthen the milking period. For each farm, a step-by-step simulation experiment allowed us to select the most appropriate modality of implementation for each management adaptation: increasing the flock size, lengthening the milking period, and increasing grazing.

For the flock size increase adaptation, two modalities were simulated. The aim of both the modalities was to compensate for the loss in milk production, not to achieve more than the initial level of milk production. A $20 \%$ increase in the size of the flock was applied in the ODM1 situation, and a 10\% increase was applied in the ODM2 situation.

The increase in milking period adaptation consists in increasing the length of the period by the number of days added and choosing when to add the days, i.e., at the beginning or at the end of the milking period. This modification results in the addition of between 15 and 30 days (see Tables A3 and A4 in Appendix B).

The increase in pasture intake occurs in the middle and at the end of the milking period (and is therefore accompanied by a decrease in the quantity of feed concentrate distributed). This increase can be planned from when the days become longer (around May 15) until less biomass is available in the pastures (around July 15). The total feed intake on pasture was thus modified by $+4 \%$ for INTENS, $+5 \%$ for EXTENS and ODMearly, and $+13 \%$ for ODMlate. 
Step by step, all the simulation results and discussions with the scientific and technical experts led to the selection of a scenario for each farm that corresponds to a satisfactory trade-off between the values of the three model outputs: household income, routine workload and total milk delivery. The selected scenarios correspond to a combination of one modality of ODM implementation (ODM1 or ODM2) and the flock management adaptations (termed COMBI).

\subsection{Outputs of the model}

Total milk production corresponds to all the milk produced by the ewes belonging to one farm over a period of one year. The routine workload is based on the time required for milking and the size of the flock. Whatever the flock size, ODM leads to a reduction of 70 minutes per day compared to a twice-a-day milking situation, equal to 192 minutes per day. The household income includes the gross product and the Common Agricultural Policy premiums minus the operating and structure costs and the loan annuity.

To evaluate the impact of a transition to ODM associated with flock management adaptations, several scenarios were simulated:

- the implementation of ODM (at the first day of milking or delayed by 8-10 weeks) with the adaptations applied one at a time;

- the implementation of ODM (at the first day of milking or delayed by 8-10 weeks) with all the combinations of adaptations aimed at selecting the combination that corresponds to a satisfactory trade-off between the three outputs for each farm.

To evaluate the predictive performance of the model, the simulation results were compared with observed data. For farms in the Inosys database, the model parameters were calibrated based on flock succession within physiological changes, the individual milk production curves and the characteristics of the forage system. The simulated and observed data for the three outputs defined above were compared. 


\section{Results}

\subsection{Evaluation of the model}

The evaluation consisted of comparing the observed value of a farm and the simulated results obtained with the original twice-a-day milking (Figure 4). Significant correlations between the simulated and observed values were observed, with $R 2$ values between 0.94 and $0.98(P<F$ $=0.001)$. For the three outputs, the linear regressions were close to one $(0.97,1.04$ and 0.99$)$, confirming that the predictive performance of the model is satisfactory for these criteria.

\subsection{Evaluation of the impact of the transition to ODM}

When the transition occurred on the first day of the milking period, the decrease in milk yield varied slightly, from 17 to $19 \%$, depending on the length of the milking period (Table 2). The decrease in household income ranged from 5 to $11 \%$ for all the farms. The largest decrease (11\%) was observed for farms that sell milk in the off-season, i.e., outside the Roquefort processing period, when milk prices are higher. Finally, the gain in the routine workload was approximately $10 \%$ for all four farms.

For a switch to ODM delayed, the original level of household income was almost reached for INTENSIVE, EXTENSIVE and ODMearly. For these farms, the gain due to less distribution of concentrates is sufficient to reduce the impact of the decrease in the volume of milk. However, it divided the gain in the routine workload obtained under the ODM1 scenario by two (Table 2). The ODM2 scenario thus appears to be less favourable for the farm type ODMlate. The decrease in milk production was close to that of the other farms, but the reduction in household income was larger because the decrease in milk yield in the ODM2 scenario occurred at the end of the milking period when the sales price of milk from this farm is higher.

\subsection{Scenarios selected to limit the losses due to the ODM transition}




\subsubsection{Impact of the flock management adaptations applied one at a time (see Tables A1} to A5 in Supplementary Materials)

Increase in the number of ewes milked: This adaptation compensated (or even more than compensated) for the decrease in total milk production. However, by affecting the number of ewes, the flock size adaptation also increased the routine workload and costs due to the distribution of feed concentrate. Consequently, this adaptation was not among the scenarios selected as a satisfactory trade-off for the three outputs (except for ODMearly, for which the milking period cannot be lengthened).

Lengthening the milking period: With ODM1 combined with $M L I$, the decrease in the milk yield was less (- $11 \%$ to $-15 \%)$, whereas a significant gain in the workload (+ 8 to $+9 \%$ ) was maintained. For INTENS and EXTENS, the association of ODM2 with MLI made it possible to reach the milk yield and the household income obtained with twice-a-day milking. The gain in the routine workload was also lower, ranging from $+6 \%$ and $+4 \%$.

Increase in the contribution of grazing to the flock's diet as the days become longer: The aim of increasing pasture intake is to reduce the cost of feeding the flock to maintain the farmer's income despite the reduction in milk yield. A very slight increase (of 1 or $2 \%$ ) in household income can be observed for the EXTENS and ODMlate farms, the largest increase being in the quantity of biomass ingested in the pasture.

\subsubsection{Impact of the combinations of flock management adaptations with a transition to}

\section{ODM for the four farms modelled}

The individual implementation of flock management adaptations did not make it possible to reach the original levels of milk production and household income while simultaneously increasing labour savings for routine work. In contrast, implementing several adaptations did make it possible to compensate for the decreases in both milk production and household income while maintaining the routine workload savings at more than 100 hours for all farms.

For all farms except ODMearly, combining increases in the length of the milking period and in pasture intake led to good trade-offs between household income, milk production and routine 
workload savings. The results were the same for all farms except ODMearly. However, the conditions of application differed, especially depending on the date on which milking began. Due to a longer initial milking period, the ODMearly farm shifted to an increase in the flock size. Obviously, the length of the milking period, the period in which the sales price of milk is highest, and whether the system is 'late' or 'early' affected the simulated results (Table 3).

For all farms (Figure 5), once-a-day milking on the first day of milking enabled the highest workload savings (225 to 323 hours), at the expense of income, with the largest decreases $(1,062$ to 2,730 Euros). By combining appropriate management adaptations with a delay in starting once-a-day milking, it was possible to stay at the level of the original income, or even higher, but the workload savings were then rather low (101 to 199 hours). The early and late farms had higher incomes and larger workloads because they had larger flocks, longer milking periods and sold off-season milk at higher prices. The decreases in their incomes and workloads were then larger than those of the INTENS and EXTENS farms, but the ranking of the scenarios was the same for each farm.

\subsection{Qualitative validation of the scenarios by breeders}

Under the assumption that ODM would be accepted in the Roquefort specifications of the protected designation of origin, the 12 breeders who participated in the meetings said that they would apply it, nine of them for sure and with the others planning to do so only under certain conditions.

Eight breeders assumed the transition ODM would occur in the middle of the milking period, around the turnout date. However, one problem was identified. The transition to the ODM could be a social obstacle. Breeders foresee that people consider that they are not going to do anything else. Actually, breeders find criticism from their peers or neighbours unacceptable.

Apart from adjusting the quantity of feed concentrate distributed, six of the breeders interviewed said they did not plan to combine any other modifications with the implementation of once-a-day milking. To preserve their forage autonomy, they did not intend to increase the 
number of ewes, as one breeder put it. One breeder explains that with a 230-day milking period, he would not have the ability to increase the number of ewes and remain autonomous. The breeders also wanted to keep a period during which they had less work. At the end of the milking period, harvesting is also finished. This timeframe corresponds to the only quiet period of the year, which breeders do not want to lose. None of the breeders planned to start or increase the size of a complementary herd, such as suckling cows or ewes, mainly because of the associated workload. The breeders prefer to stay as they are rather than increase their workloads with another flock. The breeders considered that the workload savings are worth the loss of income, which is not very large in the situation in which starting ODM is delayed, even in the absence of any other adaptations.

\section{Discussion}

In this study, the impacts of two modalities of transition to once-daily milking associated with three adaptations of flock management were evaluated using simulations.

The model developed represents the loss in milk yield reported in the literature (Negrao et al., 2001; Gonzalez-Garcia et al., 2015; Hassoun et al., 2016; Koutsouli et al., 2017). Simulations of ODM implementation also showed in a decrease in household income for farmers. The decrease can be partially or completely offset by adapting flock management, for example, by increasing the length of the milking period or by applying the transition later, around the turnout date instead of on the first day of milking. Despite the $17 \%$ decrease in milk yield (Hassoun et al., 2016), the savings in concentrates and the implementation of different leeway modalities allow a trade-off between income and workload. For example, in the ODM1 scenario, without any adaptation of flock management, the routine workload savings (approximately 250 hours) would imply a decrease in household income of 3,000 euros over one year, which was considered acceptable by the farmers (the point of view expressed during collective debates). The routine workload corresponds to animal care including feeding, mulching, scraping and milking. ODM decreases the routine workload required for a flock of 480 ewes (Hassoun et al., 
2013). Transposing the results at farm level led to a reduction of $10 \%$ in the routine workload compared with the twice-a-day milking situation. When only the workload associated with milking was taken into account, the gain was approximately $45 \%$. When the transition took place around the turnout date (ODM2), the household income reached the same level as that obtained with the original twice-a-day milking, but the gain in the workload associated with milking was divided by two (compared with the ODM1 scenario).

For each farm type, it is possible to find a combination of adaptations that enable a trade-off between the reduction in the household income and routine workload savings. Nevertheless, the diversity of farming systems also implies diversity in the leeway associated with the transition to ODM. For example, the milking period can be lengthened at the beginning or at the end of the period, and the number of days added depends on its original length. The most advantageous adaptations are those that help match milk production and the period when the milk is sold at the highest price.

At the farm level, flock management adaptations can compensate for the decrease in household income but not for the decrease in total milk yield. However, considered at the level of the whole dairy production area, the different ways of implementing ODM in farms would affect the volume of milk available for cheese production, in addition to the frequency of collection. For origin labels for which twice-a-day milking is an obligation for cheese production, a transition to ODM at the level of the dairy area would require modification of the PDO specifications, which currently do not include this management option. For example, Roquefort cheese is produced from $50 \%$ of the milk collected under the PDO specifications, and the remaining $50 \%$ is used for pressed or salted cheeses or other products (another ewe milk cheese named Pérail, yoghourt, etc.). In practice, simulations at the dairy area level can help measure the impact of the collective implementation of ODM. However, even without any change in PDO specifications, it is already possible for farms that are not involved in a cheese label to use ODM. For instance, approximately $13 \%$ of the total ewe milk produced in France, which represents approximately 450 breeders, does not comply with PDO specifications (Anonyme, 2016). This proportion increased by almost 3\% between 2010 and 2015. For other 
countries in which PDO labels do not include TDM in their specifications, the different modalities of ODM implementation tested here in a diverse range of farming systems should be the starting point for the exploration of new milking management alternatives.

ODM can reduce the routine workload. However, the decision to perform ODM1 (for the entire milking period) or ODM2 (for a specified period within the milking period) should be discussed with breeders. Only the breeders can weigh the advantages and disadvantages and consequently evaluate for which routine the workload savings make the lost income acceptable. The breeders used the simulation results to discuss their ability to apply ODM. Even if the representation used here was a simplification of the whole range of diversity that can be found in the real farms, it provides a good basis for reflection for all farmers. The breeders felt directly concerned by the simulation results and were able to discuss possible ways to implement ODM on their own farms.

The breeders interviewed noted that routine workload savings are worth a decrease in income. Their opinion was shared by New Zealand dairy cow farmers, for whom ODM could represent the opportunity to escape (some) of the daily grind of milking or to take a part-time off-farm job (Clark et al., 2006). As these authors stated, "One of the advantages is that where twice-a-day milking is not required, makes scheduling work more flexible. This flexible time (e.g. afternoons) can be used for family, leisure, or off-farm interests". The social impact of ODM on dairy cow farms was underlined by the fact that the farmers interviewed unanimously understood that ODM reduced the milk yield but were generally prepared to accept this disadvantage to achieve their short- or long-term goals. Moreover, the negative effects of ODM on milk yield can be partially offset by adopting high stocking rates or by using ODM for a specified period within the whole milking period rather than for the entire period) (Bewsell et al., 2008).

Variations in household income due to the transition to ODM observed in a diverse range of dairy sheep farms have also been observed in dairy cow farms. In fact, some authors showed that high-genetic-merit cows can be milked once per day during the whole lactation period 
without any negative impacts on their welfare or on the economic efficiency of grassland based dairy systems (Brocard et al., 2008). However, indicators of economic evaluation of two different sets of data, one from Germany and one from New Zealand, revealed that the variability of production indicators influences profit per cow and year (Kvapilik et al., 2015). In the German calculation, it is clear that after switching to ODM, the economic results of milk production became worse due to the decrease in milk yield (reductions in per cow and year profit of 155 and $380 €$, respectively). The opposite results were found in New Zealand, where the same revenues per hectare were obtained under TDM and ODM for a loss of $500 \mathrm{~kg}$ in milk production and were $12 \%$ lower per dairy cow. In per hectare ODM compared with TDM, most cost items decreased.

Similar to the results obtained here, published data indicate that the economic impacts of switching from TDM to ODM are influenced by many factors, the main ones being the expansion of milk production, inputs and the organization of work, and having the appropriate conditions for grazing. The increase in the use of grassland in the animals' diet is of major interest due to the significant non-productive function in addition to production. It is grazing plus the ecological use of land and landscape maintenance in the natural state. These goals and targets are consistent with current societal expectations regarding agroecology. Moreover, French dairy sheep farms that also enhance pastoral areas (rangelands, summer pastures, etc.) receive more CAP payments. Additionally, with the increase in the volume of milk produced, these payments for good practices may result in an increase in household income, as observed in Rayon de Roquefort, with +900 euros per labour unit in 2016. Enhancing appropriate grazing management is thus a promising way to facilitate the introduction of ODM in dairy sheep farms.

\section{Conclusion}

Regarding the diversity of farming systems and labour benefits, despite the decrease in milk production, once-a-day milking (ODM) is a good compromise between flexible workload management and the performances of dairy sheep farms. More than new grazing management 
alternatives, ODM offers new alternative practices that could be associated with new standards of living to attract young farmers to produce ewe milk in the Mediterranean region. Moreover, the practices associated with the implementation of ODM (more grazing, less concentrates, etc.) are consistent with the current societal expectations of agroecology, in addition to being an alternative way to develop and improve the sustainability of dairy sheep farming systems.

\section{Acknowledgements}

These findings are outcomes of the research contract ROQUEFORT'IN (2010-2013), co-funded by the FUI, the FEDER, the Conseil Régional de Midi-Pyrénées, the Conseils Généraux de l'Aveyron et du Tarn, and the Communauté d'Agglomération du Grand Rodez. The authors thank all the local actors from the French Rayon de Roquefort and the scientific partners for contributing to this study.

\section{References}

Amstrong, D.P., Ho, C., 2009. Economic impact of switching to once-a-day milking on a dairy farm in northern Victoria. AFBM Journal 6, 55--62

Anonyme, 2016. L'élevage ovin, facteur de résilience. In: I'élevage., E.d. (Ed.), Dossier annuel Ovins 2016. Perspectives 2017. Idele CNE, p. pp. 40.

Bewsell, D., Clark, D.A., Dalley, D.E., 2008. Understanding motivations to adopt once-a-day milking amongst New Zealand dairy farmers. J. Agr. Educ. Ext 14, 69-80.

Bood, R.P., Postma, T., 1997. Strategic learning with scenarios. Eur. Manag. J.I 15, 633-647. Brocard, V., Portier, B., Porhiel, J.Y., Lopez, C., 2008. Impacts of compact calvings and oncea-day milking in grassland based systems. EAAP Congress, Vilnius.

Castillo, V., Such, X., Caja, G., Casals, R., Salama, A.A.K., Albanell, E., 2009. Long- and shortterm effects of omitting two weekend milkings on the lactational performance and mammary tight junction permeability of dairy ewes. J. Dairy Sci. 92, 3684-3695.

Clark, D.A., Phyn, C.V.C., Tong, M.J., Collis, S.J., Dalley, D.E., 2006. A systems comparison of once- versus twice-daily milking of pastured dairy cows. J. Dairy Sci. 89, 1854-1862. 
Gonzalez-Garcia, E., Tesniere, A., Camous, S., Bocquier, E., Barillet, F., Hassoun, P., 2015. The effects of parity, litter size, physiological state, and milking frequency on the metabolic profile of Lacaune dairy ewes. Domest. Anim. Endocrin. 50, 32-44.

Hassoun, P., Allain, C., Marnet, P.G., Gonzalez-Garcia, E., Larroque, H., Vanbergue, E., Dessauge, F., Dzidic, A., Autran, P., Portes, D., Guitard, J.P., Lagriffoul, G., Tesniere, A., Morin, E., de Boissieu, C., Moulin, C.H., Lurette, A., Barillet, F., 2016. Once daily milking in Lacaune dairy ewes: Synthesis of a five year study conducted in France. Inra Prod. Anim. 29, 57-71.

Hassoun, P., Vernhes, G., Autran, P., 2013. Effet du rythme de traite des brebis laitières Lacaune sur le temps de travail et les consommations en eau et en électricité en salle de traite. Effects of milking frequency in Lacaune dairy ewes on working time, water and electricity consumption at milking parlour. In: Idele, I. (Ed.), Rencontre Recherche Ruminants, Paris, France, p. pp. 249.

Jousseins, C., Fagon, J., Belvèze, J., Servière, G., 2015. Livestock Farm Networks, a system at the center of French farming development. Rev Elev. Med. Vet Trop. 107-113.

Knight, T.W., Atkinson, D.S., Haack, N.A., Palmer, C.R., Rowland, K.H., 1993. Effects of suckling regime on lamb growth-rates and milk yields of dorset ewes. New Zeal. J. Agr. Res. 36, 215-222.

Komara, M., Giger-Reverdin, S., Marnet, P.G., Roussel, S., Duvaux-Ponter, C., 2010. The combined effects of milking frequency and feeding level on dairy goat welfare and milk emission characteristics in late lactation. App. Anim. Behav. Sci. 127, 96-103.

Koutsouli, P., Simitzis, P., Theodorou, G., Massouras, T., Bizelis, I., Politis, I., 2017. The effect of milking frequency reduction from twice to once daily on mammary physiology and animal welfare of two dairy Greek sheep breeds. Small Ruminant Res. 147, 18-24.

Kvapilik, J., Hanus, O., Roubal, P., Filip, V., 2015. Economic metaanalysis of impact of once a day milking. Bulgarian J. Agr. Sci. 21, 419-428.

Mocquot, J.C., 1978. Studies on milk-production in cattle .2. Usefulness of part lactation records for selection .c. Prediction of total yield corrected for lactation length. Ann. Genet. Sel. Anim. 10, 359-376.

Negrao, J.A., Marnet, P.G., Labussiere, J., 2001. Effect of milking frequency on oxytocin release and milk production in dairy ewes. Small Ruminant Res 39, 181-187.

Nudda, A., Bencini, R., Mijatovic, S., Pulina, G., 2002. The yield and composition of milk in Sarda, Awassi, and Merino sheep milked unilaterally at different frequencies. J. Dairy Sci. 85, 2879-2884. 
O'Driscoll, K., O'Brien, B., Gleeson, D., Boyle, L., 2010. Milking frequency and nutritional level affect grazing behaviour of dairy coAmstrong, D.P., Ho, C., 2009. Economic impact of switching to once-a-day milking on a dairy farm in northern Victoria. AFBM Journal 6, 55--62 Negrao, J.A., Marnet, P.G., Labussiere, J., 2001. Effect of milking frequency on oxytocin release and milk production in dairy ewes. Small Ruminant Res. 39, 181-187.

Nudda, A., Bencini, R., Mijatovic, S., Pulina, G., 2002. The yield and composition of milk in Sarda, Awassi, and Merino sheep milked unilaterally at different frequencies. J. Dairy Sci. 85, 2879-2884.

O'Driscoll, K., O'Brien, B., Gleeson, D., Boyle, L., 2010. Milking frequency and nutritional level affect grazing behaviour of dairy cows: A case study. App. Anim. Behav. Sci. 122, 77-83.

Prieto, N., Bodas, R., Lopez-Campos, O., Andres, S., Lopez, S., Giraldez, F.J., 2013. Effect of sunflower oil supplementation and milking frequency reduction on sheep milk production and composition. J. Anim. Sci. 91, 446-454.

Remond, B., Pomies, D., 2005. Once-daily milking of dairy cows: a review of recent French experiments. Anim. Res. 54, 427-442.

Seegers, J., Chauvat, S., N'Guyen, T.B., Clement, B., 2003. Le travail d'astreinte en élevage bovin laitier. Synthèse nationale d'enquêtes bilan travail. Analyse des aspirations et des solutions envisagées par les éleveurs du dispositif Réseaux d'élevage. Réf RM 855, 56 p.

Stelwagen, K., Phyn, C.V.C., Davis, S.R., Guinard-Flament, J., Pomies, D., Roche, J.R., Kay, J.K., 2013. Reduced milking frequency: Milk production and management implications. J. Dairy Sci. 96, 3401-3413.

Stockdale, C.R., 2006. Influence of milking frequency on the productivity of dairy cows. Austr. J. Exp. Agr. 46, 965-974.

Torres, A., Castro, N., Arguello, A., Capote, J., 2013. Comparison between two milk distribution structures in dairy goats milked at different milking frequencies. Small Ruminant Res. 114, 161-166.

Table 1. Characteristics of the four farms modelled in this study under the baseline scenario with twice-a-day milking (dairy ewe flock in the Rayon de Roquefort area) (from Idele, 2012)

\begin{tabular}{|c|c|c|c|c|c|c|c|c|c|}
\hline Location & $\begin{array}{l}\text { Labour } \\
\text { unit }\end{array}$ & $\begin{array}{l}\text { Usable } \\
\text { agricultural } \\
\text { area (ha) }\end{array}$ & $\begin{array}{l}\text { Forage } \\
\text { stored }\end{array}$ & $\begin{array}{l}\text { Ewes } \\
\text { (n) }\end{array}$ & $\begin{array}{l}\text { Start } \\
\text { milking } \\
\text { date }\end{array}$ & $\begin{array}{l}\text { End } \\
\text { milking } \\
\text { date }\end{array}$ & $\begin{array}{l}\text { Milk } \\
\text { produc- } \\
\text { tion } \\
\text { (in hl) }\end{array}$ & $\begin{array}{c}\text { House } \\
\text { hold } \\
\text { income }^{a} \\
\text { (in euros) }\end{array}$ & $\begin{array}{l}\text { Routine } \\
\text { workload } \\
\text { (in hours) }\end{array}$ \\
\hline
\end{tabular}




\begin{tabular}{lccccccccc}
$\begin{array}{l}\text { Ségala } \\
\text { INTENS }\end{array}$ & 2.0 & 52 & Hay/ silage & 310 & $20 / 11$ & $15 / 07$ & 912 & 21,244 & 2,521 \\
$\begin{array}{l}\text { Causses sud - } \\
\text { EXTENS }\end{array}$ & 2.3 & 96 & Hay & 390 & $20 / 02$ & $31 / 08$ & 853 & 21,231 & 2,250 \\
$\begin{array}{l}\text { Ségala } \\
\begin{array}{l}\text { ODMearly } \\
\text { Causses nord } \\
\text { / }\end{array}\end{array}$ & 2.5 & 63 & Hay/ silage & 410 & $01 / 09$ & $31 / 05$ & 1350 & 24,820 & 3,230 \\
& 2.5 & 89 & Hay/ silage & 480 & $05 / 03$ & $15 / 11$ & 1483 & 29,936 & 3,325 \\
\hline
\end{tabular}

a Income: Available income per labour unit

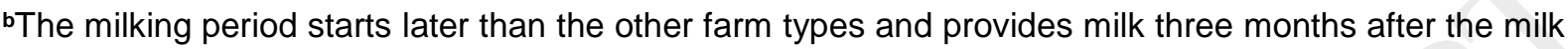
collection dates laid down in the protected designation of origin Roquefort specifications.

cThe milking period starts very early, two and half months before the milk collection dates laid down in the protected designation of origin Roquefort specifications.

Table 2. Evaluation of the impact of the once-a-day milking implemented on the first day of the milking period (ODM1) and around the turnout date (ODM2) with no other flock management adaptations (except adjustment of the quantity of concentrates distributed) for each of the four farms modelled.

\begin{tabular}{llccccc}
\hline & \multicolumn{3}{l}{$\begin{array}{l}\text { Scenarios for ODM1 with no adaptation } \\
\text { in flock management }\end{array}$} & $\begin{array}{c}\text { Scenarios } \\
\text { adaptation in }\end{array}$ & $\begin{array}{c}\text { for ODM2 } \\
\text { ine management }\end{array}$ \\
\hline $\begin{array}{l}\text { Milk prod- } \\
\text { uction } \\
\text { (in hl) }\end{array}$ & $\begin{array}{c}\text { Household } \\
\text { income } \\
\text { (in Euros) }\end{array}$ & $\begin{array}{c}\text { Routine } \\
\text { workloads (in } \\
\text { hours) }\end{array}$ & $\begin{array}{c}\text { Milk } \\
\text { production } \\
\text { (in hl) }\end{array}$ & $\begin{array}{c}\text { Household } \\
\text { income } \\
\text { (in Euros) }\end{array}$ & $\begin{array}{c}\text { Routine } \\
\text { workloads } \\
\text { (in hours) }\end{array}$ \\
\hline INTENS & 748 & 19970 & 2244 & 857 & 21244 & 2370 \\
EXTENS & 691 & 20169 & 2025 & 768 & 21019 & 2115 \\
ODMearly & 1121 & 22090 & 2907 & 1256 & 24572 & 3036 \\
ODMlate & 1216 & 27541 & 3026 & 1364 & 28739 & 3126 \\
\hline
\end{tabular}

Table 3. Evaluation of scenarios modelling two modalities of implementation of once-a-day milking: on the first day of the milking period (ODM1) and around the turnout date (ODM2) associated with the most appropriate combination of technical levers (respectively denoted ODM1 with $\mathrm{COMBI}$ and ODM2 with COMBI) (i.e., the combination that allows breeders to prioritize their household income and routine workload savings) for the four farms modelled with respect to the twice-a-day milking baseline index (100). 


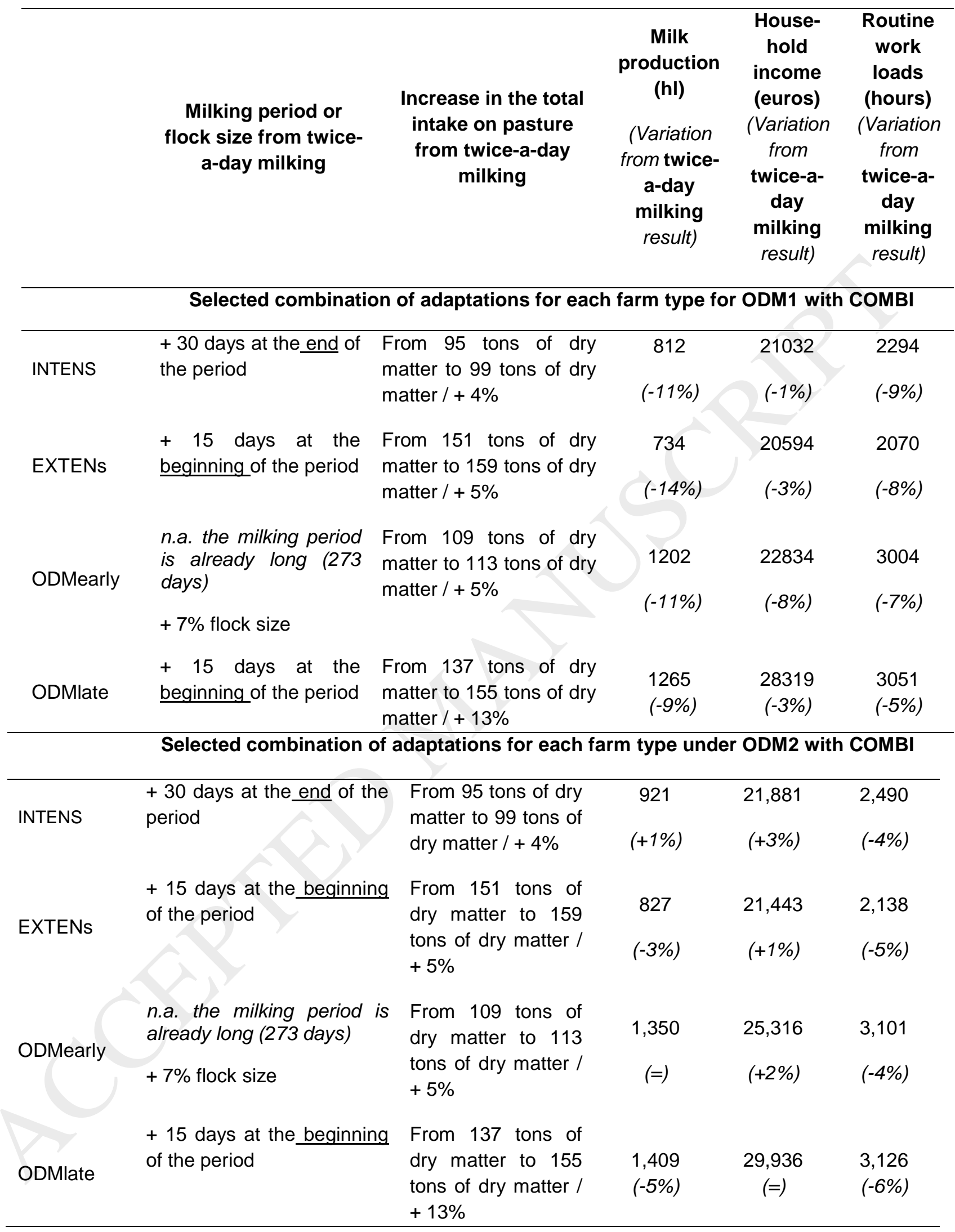

Figure captions: 
Figure 1. Schematic representation of the involvement of the actors in the participatory approach used to evaluate the impact of the transition to once-a-day milking on dairy sheep farms in the Rayon de Roquefort.

Figure 2. General framework of the flock module: succession of events reflecting changes in physiological stages, diets and milk collection.

Figure 3. General framework of the forage system module.

Figure 4. Comparison of observed and simulated data for three outputs of the model for the calibration process for four dairy sheep farms in the Rayon de Roquefort: milk yield, household income and routine workload. INTENS: Segala farming system; EXTENS: Causses Nord farming system; ODMearly: Segala farming system with early milk collection; and ODMlate: Causses Nord farming system with late milk collection.

Figure 5. Routine workload per hectolitre of milk according to the household income per hectolitre for four dairy sheep farms in the Rayon de Roquefort under five scenarios. INTENS: Segala farming system; EXTENS: Causses Nord farming system; ODMearly: Segala farming system with early milk collection; and ODMlate: Causses Nord farming system with late milk collection. TDM: twice-a-day milking reference scenario; ODM1: once-a-day milking introduced on the first day of the milking period; ODM2: transition to the once-a-day milking period around the turnout date; ODM1 with COMBI: transition to once-a-day milking on the first day of the milking period and combination of technical levers that allows breeders to prioritize their household income and the gain in the routine workload; ODM2 with COMBI: transition to oncea-day milking around the turnout date and combination of technical levers that allows breeders to prioritize their household income and the routine workload savings. 


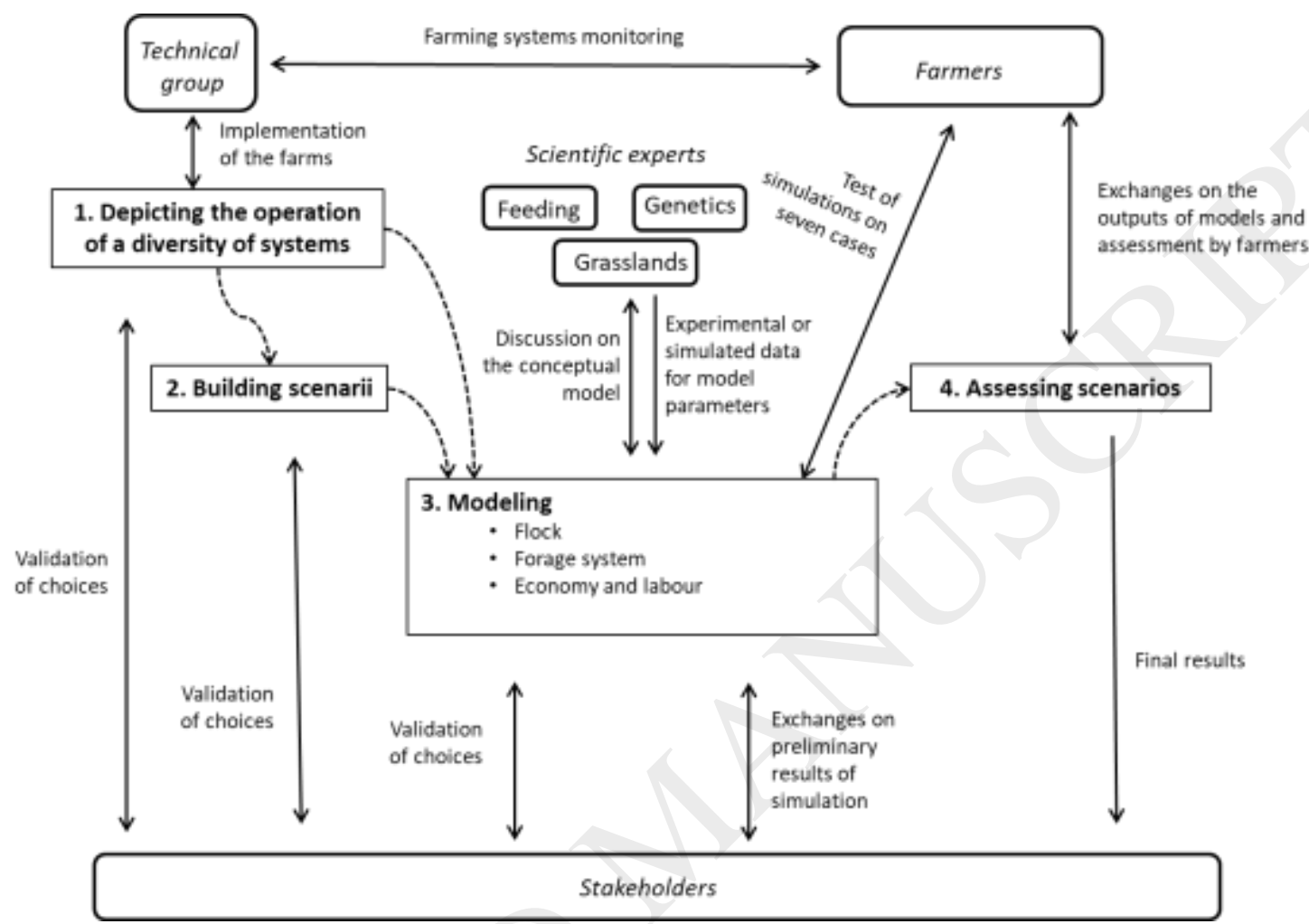

Actor participating to the modelling process

$\mathrm{x}$ Step $\mathrm{x}$ of the modelling process conducted by $Y$ institutions

Figure 1 


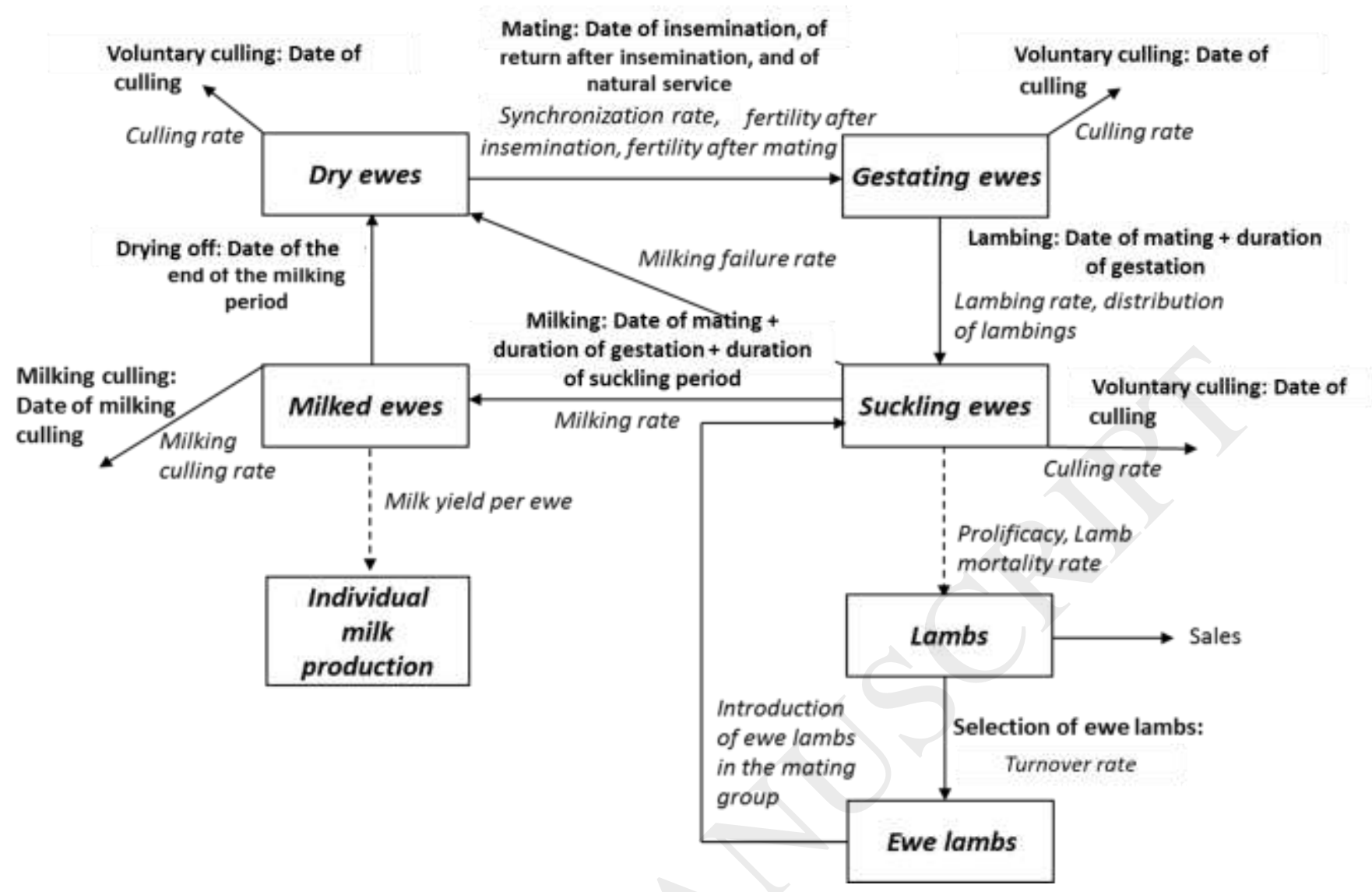

Figure 2 
- Crop rotation $x$ forage use (CropForage System, CFS)

- Area of each CFS

- Spring grazing area for leys

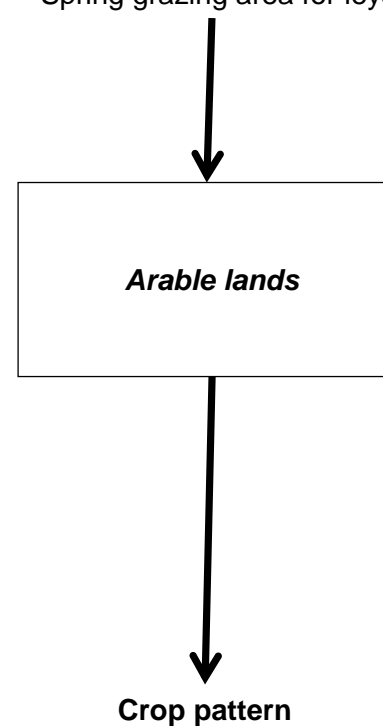

Spring grazing area

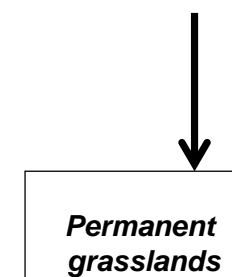

Feed supply

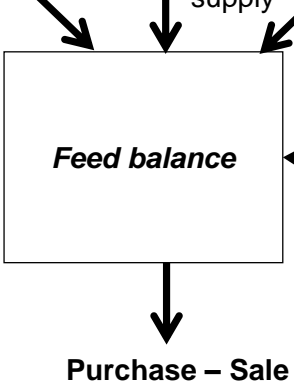

(hay, grain, straw)
Contribution of

rangelands to grazing

Feed

supply

Figure 3 

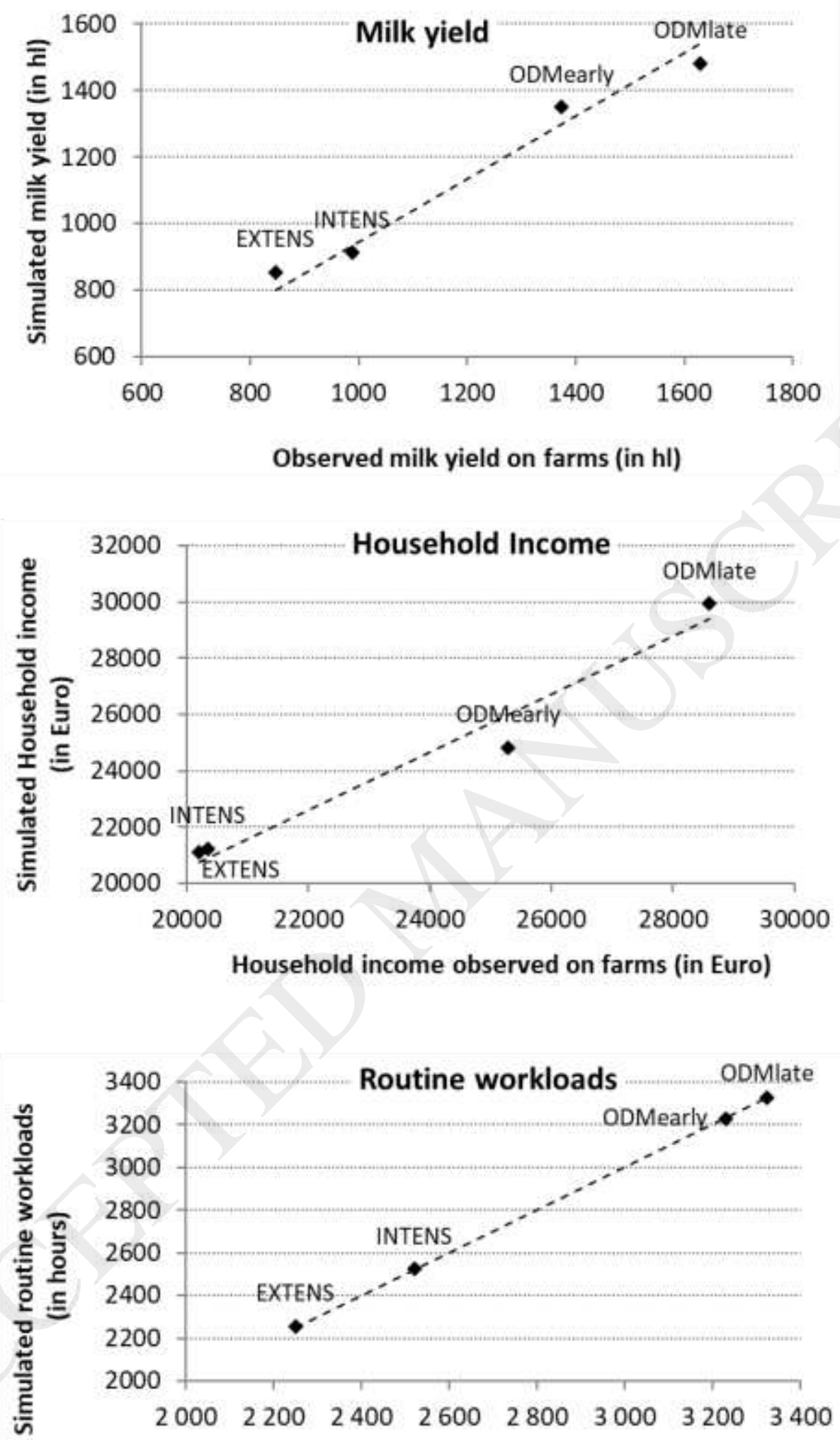

Routine workloads observed on farms (in hours)

Figure 4 


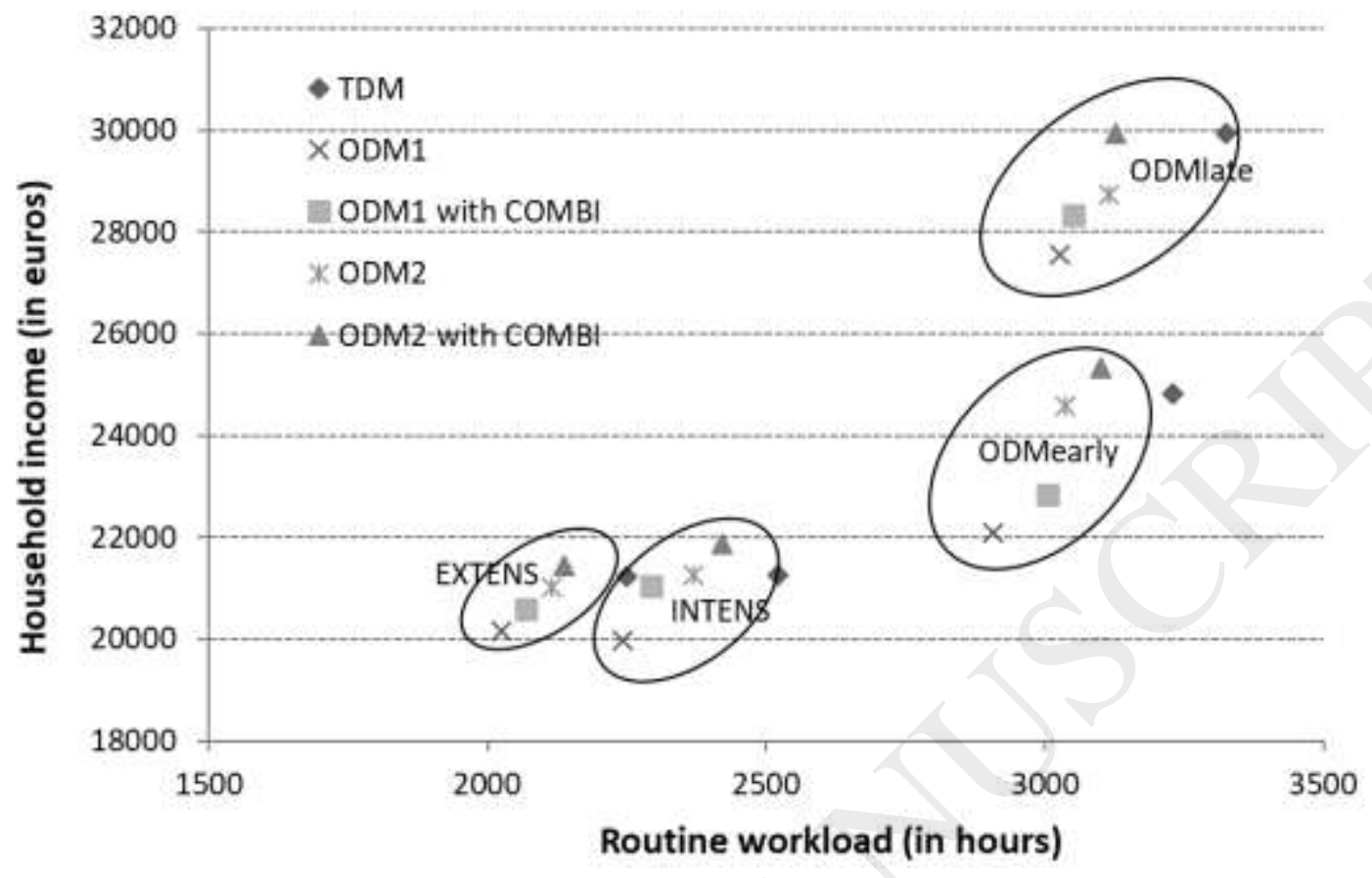

Figure 5

Annexe A. Elaboration of the individual scenarios

Table A1. Evaluation of the impact of the once-a-day milking implemented on the first day of the milking period (ODM1) and after a delay of 8-10 weeks (ODM2) with increasing flock size adaptations for each of the four farms modelled, with respect to the twice-a-day milking baseline index (100).

\begin{tabular}{|c|c|c|c|c|c|c|}
\hline \multirow{2}{*}{ 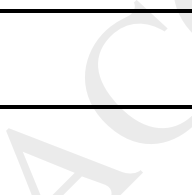 } & \multicolumn{3}{|c|}{$\begin{array}{l}\text { Scenarios for ODM1 with increasing } \\
\text { the flock size }(+20 \%)\end{array}$} & \multicolumn{3}{|c|}{$\begin{array}{l}\text { Scenarios for ODM2 with increasing } \\
\text { the flock size }(+10 \%)\end{array}$} \\
\hline & $\begin{array}{l}\text { Milk } \\
\text { production }\end{array}$ & $\begin{array}{l}\text { Household } \\
\text { income }\end{array}$ & $\begin{array}{l}\text { Routine } \\
\text { work load }\end{array}$ & $\begin{array}{l}\text { Milk } \\
\text { production }\end{array}$ & $\begin{array}{l}\text { Household } \\
\text { income }\end{array}$ & $\begin{array}{l}\text { Routine } \\
\text { work load }\end{array}$ \\
\hline INTENS & 98 & 97 & 96 & 96 & 101 & 97 \\
\hline EXTENS & 97 & 98 & 101 & 111 & 100 & 105 \\
\hline ODMearly & 100 & 91 & 98 & 100 & 101 & 96 \\
\hline ODMlate & 99 & 98 & 100 & 89 & 101 & 102 \\
\hline
\end{tabular}


Table A2 Evaluation of the impact of the once-a-day milking implemented on the first day of the milking period (ODM1) with an increase in the milking period for each of the four farms modelled, with respect to the twice-a-day milking baseline index (100).

\begin{tabular}{|c|c|c|c|c|}
\hline & \multirow[b]{2}{*}{ Description } & \multicolumn{3}{|c|}{$\begin{array}{l}\text { Scenarios for ODM1 with increasing the } \\
\text { milking period }\end{array}$} \\
\hline & & $\begin{array}{l}\text { Milk } \\
\text { production }\end{array}$ & $\begin{array}{l}\text { Household } \\
\text { income }\end{array}$ & $\begin{array}{l}\text { Routine work } \\
\text { load }\end{array}$ \\
\hline INTENS & $\begin{array}{l}+30 \text { days at the end of the } \\
\text { period }\end{array}$ & 89 & 98 & 91 \\
\hline EXTENS & $\begin{array}{l}+15 \text { days at the beginning of } \\
\text { the period }\end{array}$ & 87 & 96 & 92 \\
\hline ODMearly & $\begin{array}{l}\text { n.a. the milking period is } \\
\text { already long ( } 273 \text { days) }\end{array}$ & n.a & n.a & n.a \\
\hline ODMlate & $\begin{array}{l}+15 \text { days at the beginning of } \\
\text { the period }\end{array}$ & 85 & 94 & 92 \\
\hline
\end{tabular}

Table A3 Evaluation of the impact of the once-a-day milking implemented with an 8-10-week delays around the turnout date (ODM2) with an increase in the milking period for each of the four farms modelled, with respect to the twice-a-day milking baseline index (100).

\begin{tabular}{|c|c|c|c|c|}
\hline & \multirow[b]{2}{*}{ Description } & \multicolumn{3}{|c|}{$\begin{array}{l}\text { Scenarios for ODM2 with increasing the } \\
\text { milking period }\end{array}$} \\
\hline & & $\begin{array}{l}\text { Milk } \\
\text { production }\end{array}$ & $\begin{array}{l}\text { Household } \\
\text { income }\end{array}$ & $\begin{array}{l}\text { Routine work } \\
\text { load }\end{array}$ \\
\hline INTENS & $\begin{array}{l}+30 \text { days at the end of the } \\
\text { period }\end{array}$ & 101 & 102 & 96 \\
\hline EXTENS & $\begin{array}{l}+15 \text { days at the beginning of } \\
\text { the period }\end{array}$ & 97 & 100 & 95 \\
\hline ODMearly & $\begin{array}{l}\text { n.a. the milking period is } \\
\text { already long ( } 273 \text { days) }\end{array}$ & n.a & n.a & n.a \\
\hline ODMlate & $\begin{array}{l}+15 \text { days at the beginning of } \\
\text { the period }\end{array}$ & 95 & 97 & 94 \\
\hline
\end{tabular}

Table A4 Evaluation of the impact of the once-a-day milking implemented on the first day of the milking period (ODM1) with an increasing in pasture intake for each of the four farms modelled, with respect to the twice-a-day milking baseline index (100).

\begin{tabular}{llccc}
\hline & & \multicolumn{3}{c}{$\begin{array}{c}\text { Scenarios for ODM1 with increasing } \\
\text { the pasture intake }\end{array}$} \\
\hline & $\begin{array}{l}\text { Description } \\
\text { Increasing the total TDM intake on } \\
\text { pasture from TDM to ODM1 modified } \\
\text { From 95 tons of dry matter to 99 tons of } \\
\text { dry matter } /+4 \%\end{array}$ & $\begin{array}{c}\text { Milk } \\
\text { production }\end{array}$ & $\begin{array}{c}\text { Household } \\
\text { income }\end{array}$ & $\begin{array}{c}\text { Routine } \\
\text { work } \\
\text { INTENS }\end{array}$ \\
\hline
\end{tabular}




\begin{tabular}{lllll}
\hline EXTENS & $\begin{array}{l}\text { From } 151 \text { tons of dry matter to } 159 \text { tons } \\
\text { of dry matter } /+5 \%\end{array}$ & 81 & 94 & 90 \\
ODMearly & $\begin{array}{l}\text { From } 109 \text { tons of dry matter to } 113 \text { tons } \\
\text { of dry matter } /+5 \%\end{array}$ & 83 & 89 & 90 \\
ODMlate & $\begin{array}{l}\text { From } 137 \text { tons of dry matter to } 155 \text { tons } \\
\text { of dry matter } /+13 \%\end{array}$ & 82 & 94 & 91 \\
\hline
\end{tabular}

Table A5 A4 Evaluation of the impact of the once-a-day milking implemented with a 8-10-week delays around the turnout date (ODM2) with an increase in pasture intake for each of the four farms modelled, with respect to the twice-a-day milking baseline index (100).

\begin{tabular}{|c|c|c|c|c|}
\hline & \multirow[b]{2}{*}{$\begin{array}{l}\text { Description } \\
\text { Increasing the total intake on pasture } \\
\text { from TDM to ODM2 modified }\end{array}$} & \multicolumn{3}{|c|}{$\begin{array}{c}\text { Scenarios for ODM2 with increasing } \\
\text { the pasture intake }\end{array}$} \\
\hline & & $\begin{array}{c}\text { Milk } \\
\text { Production }\end{array}$ & $\begin{array}{l}\text { Household } \\
\text { income }\end{array}$ & $\begin{array}{c}\text { Routine } \\
\text { work } \\
\text { load }\end{array}$ \\
\hline INTENS & $\begin{array}{l}\text { From } 95 \text { tons of dry matter to } 99 \text { tons of } \\
\text { dry matter } /+4 \%\end{array}$ & 94 & 100 & 94 \\
\hline EXTENS & $\begin{array}{l}\text { From } 151 \text { tons of dry matter to } 159 \text { tons } \\
\text { of dry matter } /+5 \%\end{array}$ & 92 & 99 & 94 \\
\hline ODMearly & $\begin{array}{l}\text { From } 109 \text { tons of dry matter to } 113 \text { tons } \\
\text { of dry matter } /+5 \%\end{array}$ & 93 & 99 & 94 \\
\hline ODMlate & $\begin{array}{l}\text { From } 137 \text { tons of dry matter to } 155 \text { tons } \\
\text { of dry matter } /+13 \%\end{array}$ & 92 & 99 & 94 \\
\hline
\end{tabular}




\section{Appendix B. Description of the model}

Table A1. Flock events: Description of the parameters used in the flock model for the farm-type INTENS

\begin{tabular}{|c|c|c|c|c|}
\hline $\begin{array}{c}\text { Parameters values for INTENS } \\
\text { Description }\end{array}$ & Notation & $\begin{array}{l}\text { Value for ewe } \\
\text { lambs }\end{array}$ & Value for ewes & $\begin{array}{c}\text { Modification by } \\
\text { the transition to } \\
\text { the once-a-day } \\
\text { milking }\end{array}$ \\
\hline \multicolumn{5}{|l|}{ Flock characteristics } \\
\hline 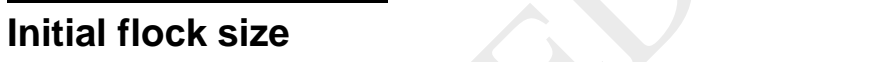 & $F S_{0}$ & 100 ewe lambs & 250 ewes & Yes* \\
\hline Ewe intake in dry matter during one day & $E W E_{\text {intake }}$ & & $\begin{array}{l}2.5 \mathrm{~kg} / \mathrm{DM} \text { during suckling } \\
3.2 \mathrm{~kg} / \mathrm{DM} \text { for the beginning } \\
\text { of milking } \\
2.5 \text { at the end of the milking } \\
1.7 \mathrm{~kg} / \mathrm{DM} \text { during gestation }\end{array}$ & No \\
\hline \multicolumn{5}{|l|}{ Milk yield } \\
\hline Individual milk yield at the first day of milking & $M Y_{B E G}$ & $2.5 \mathrm{~L}$ & $3 \mathrm{~L}$ & Yes* \\
\hline $\begin{array}{l}\text { First coefficient } 1 \text { of the curve of the individual } \\
\text { milking production }\end{array}$ & $a$ & 0.0028 & 0.0021 & No \\
\hline $\begin{array}{l}\text { Second coefficient of the curve of the individual } \\
\text { milking production }\end{array}$ & $b$ & 0.0049 & 0.0052 & No \\
\hline \multicolumn{5}{|l|}{ Physiological parameters } \\
\hline Culling rate & $\theta_{c}$ & n.a & 0.05 & Yes $^{*}$ \\
\hline Culling rate during milking & $\Theta_{C M}$ & n.a & {$[0.02,0.1,0.14]$} & Yes $^{*}$ \\
\hline Duration of a natural ovarian cycle & $d_{\text {cycle }}$ & 17 days & 17 days & No \\
\hline Fertility rate & $\theta_{F}$ & 0.75 & 0.7 & Yes* \\
\hline Gestation period & d_gest & 147 days & 147 days & No \\
\hline Insemination rate & $\theta_{I A}$ & 0.65 & 0.8 & Yes* \\
\hline
\end{tabular}




\begin{tabular}{|c|c|c|c|c|}
\hline $\begin{array}{l}\text { Lambing distribution after a failure of IA: mean } \\
\text { date }\end{array}$ & $L_{m 2}$ & $D_{I A}+$ & $\left.\left(\frac{t-D_{I A}}{d_{\text {cycle }}}\right)\right] \times d_{\text {cycle }}$ & No \\
\hline Lambing distribution after a failure of IA: variance & $L_{s 2}$ & & 2.82 days & No \\
\hline $\begin{array}{l}\text { Lambing distribution after insemination: mean } \\
\text { date }\end{array}$ & $L_{m 1}$ & & $D_{I A}+d_{g e s t}$ & No \\
\hline Lambing distribution after insemination: variance & $L_{s 1}$ & & 1.73 days & No \\
\hline $\begin{array}{l}\text { Lambing distribution for ewes which are not } \\
\text { synchronized: mean }\end{array}$ & $L_{m 3}$ & $D_{M N}$ & $+\frac{d_{\text {mating }}}{2}+d_{\text {gest }}$ & No \\
\hline $\begin{array}{l}\text { Lambing distribution for ewes which are not } \\
\text { synchronized: variance }\end{array}$ & $L_{s 3}$ & & 3.16 days & No \\
\hline Lambing rate & $\theta_{L}$ & 0.93 & 0.95 & Yes $^{*}$ \\
\hline $\begin{array}{l}\text { Mating distribution after synchronization for Al: } \\
\text { mean date }\end{array}$ & $M_{m 1}$ & $D_{M N}+$ & $\left|\left(\frac{t-D_{I A}}{d_{\text {cycle }}}\right)\right| \times d_{\text {cycle }}$ & \\
\hline $\begin{array}{l}\text { Mating distribution after synchronization for Al: } \\
\text { variance }\end{array}$ & $M_{s 1}$ & & 2.82 & \\
\hline $\begin{array}{l}\text { Mating distribution for ewes which are not } \\
\text { synchronized: mean date }\end{array}$ & $M_{m 1}$ & & $M_{M N}+\frac{d_{\text {mating }}}{2}$ & \\
\hline $\begin{array}{l}\text { Mating distribution for ewes which are not } \\
\text { synchronized: variance }\end{array}$ & $M_{s 1}$ & & 3.16 days & \\
\hline Mortality rate & $\mu_{M}$ & 0.04 & 0.04 & Yes* $^{*}$ \\
\hline Prolificacy rate & $\theta_{P}$ & 1.6 & 1.67 & Yes* \\
\hline Rate of abortion & $\theta_{A}$ & 0.01 & 0.01 & Yes* \\
\hline Rate of ewe lamb mortality & $\mu_{M}$ & 0.07 & 0.07 & Yes $^{*}$ \\
\hline Rate of turn over & $\Theta_{R}$ & n.a & 0.27 & Yes* \\
\hline Suckling period & d_suck & 28 days & 28 days & No \\
\hline Milking rate & $\theta_{M}$ & 0.97 & 0.95 & Yes $^{*}$ \\
\hline
\end{tabular}

n.a: not applicable; * The data are based on technical reports for the four farm types modelled, which are available on the website http://idele.fr/rss/publication/idelesolr/recommends/cas-types-ovins-lait-du-rayon-de-roquefort.htm/ 
Table A2. Flock events: description of the variables used in the flock model

\begin{tabular}{|c|c|c|c|}
\hline $\begin{array}{l}\text { Variables } \\
\text { Notation }\end{array}$ & Description & $\begin{array}{c}\text { Varies } \\
\text { according to } \\
\ldots\end{array}$ & Sources \\
\hline EWED $_{D}$ & Batch size of dried ewes & $\mathrm{t}$ & $\begin{array}{c}\text { Common management } \\
\text { practice }\end{array}$ \\
\hline $\mathrm{EWE}_{\mathrm{G}}$ & Batch size of gestating ewes & $\mathrm{t}$ & $\begin{array}{c}\text { Common management } \\
\text { practice }\end{array}$ \\
\hline EWEs & Batch size of suckling ewes & $\mathrm{t}$ & $\begin{array}{c}\text { Common management } \\
\text { practice }\end{array}$ \\
\hline EWE $_{M}$ & Batch size of milked ewes & $\mathrm{t}$ & $\begin{array}{c}\text { Common management } \\
\text { practice }\end{array}$ \\
\hline EWE_LAMB & Batch size of ewe lambs & $\mathrm{t}$ & $\begin{array}{l}\text { Common management } \\
\text { practice }\end{array}$ \\
\hline & Number of lambs & $\mathrm{t}$ & $\begin{array}{c}\text { Common management } \\
\text { practice }\end{array}$ \\
\hline MP & $\begin{array}{l}\text { The milk yield of the whole flock is simulated using } \\
\text { predictive individual lactation curves }\end{array}$ & $\mathrm{t}, \mathrm{t}_{1}$ & Lagriffoul et al., 2003 \\
\hline $\begin{array}{l}\text { DIET }_{F S} \\
\text { With FS } \in[1 \text {, } \\
\text { number of feeding } \\
\text { steps] }\end{array}$ & $\begin{array}{l}\text { DIETFS: Composition of the diet corresponding to the } \\
\text { feeding step FS and distributed to the animals in the } \\
\text { correspondent physiological stage. Changes the diet } \\
\text { according to period of the year and the physiological } \\
\text { stage of the animals. Diet change time is defined by the } \\
\text { number of feeding steps and the length of each step }\end{array}$ & $t, p$ & Technical report* \\
\hline
\end{tabular}

Technical reports* for the four farm types modelled are available on the website http://idele.fr/rss/publication/idelesolr/recommends/cas-typesovins-lait-du-rayon-de-roquefort.html 